\title{
NOTA EM HOMENAGEM AO PROFESSOR PEDRO PAULO A. FUNARI
}

Julio Cesar Magalhães de Oliveira ${ }^{1}$

Ingressei no curso de graduação em História da Universidade Estadual de Campinas em 1995 e fui aluno do professor Pedro Paulo A. Funari desde o primeiro semestre daquele ano. Se dediquei minha carreira à História Antiga foi em grande parte graças àquela disciplina, a primeira de tantas outras ministradas por ele que frequentei entre a graduação e o mestrado. Lembro-me do prazer de acompanhar suas aulas expositivas, que sempre nos apresentavam um campo de problemas, mais do que uma narrativa acabada; das discussões com que procurava engajar os alunos em uma produção autônoma do conhecimento; enfim, da descoberta estimulante (para um jovem estudante) de uma forma diversa de pensar a História que escrevemos, não como mímesis do passado, mas como diégesis, junção de elementos esparsos, construção sempre do e no presente. Com o tempo, vejo que muito do que tento ser como professor se espelha no seu exemplo, da postura em sala ao próprio modo de compreender o que é uma aula.

Foi naquele mesmo ano que li pela primeira vez o seu livro Cultura popular na Antiguidade Clássica, não na edição brasileira de 1989, mas na tradução espanhola de 1991, La cultura popular en la Antigüedad Clásica. Para mim, como para muitos de seus orientandos que iniciamos nossas pesquisas nos anos 1990, a leitura desse livro pouco convencional foi um estímulo para repensarmos a História Antiga de um outro ponto de vista, "a partir de baixo". Escrito no contexto da redemocratização do país, em um momento de alargamento dos debates teóricos e do surgimento de uma outra postura ético-política entre os historiadores brasileiros, ele rompia com o pior legado do regime autoritário e repressor de 1964-1985 à História Antiga, o de "estigma de área do conhecimento histórico marcada pela alienação intelectual, pelo afastamento de questões do presente e pelo elitismo e conservadorismo" (Glaydson Silva). Valorizando as elaborações culturais populares a partir dos grafites de Pompeia, ele propunha uma visão de História menos parcial e redutora do que aquela restrita à visão dos dominantes. Voltado a um público

\footnotetext{
1 Professor Doutor, Universidade de São Paulo, São Paulo, Brasil. E-mail: jcmagalhaesoliveira@gmail.com
} 
amplo, o livro rompia de forma deliberada com o eruditismo elitista tão característico da disciplina. Sua ousadia estava também na proposta de não apenas traduzir, mas recriar no nosso contexto cultural os grafites de Pompeia, de forma a aproximar o leitor desse mundo distante. Ao mesmo tempo, porém, o grande número de resenhas publicadas em revistas científicas entre 1989 e 1994 mostra o impacto que o livro teve na própria academia. Na verdade, não seria exagerado dizer que o livro se tornou um marco, talvez o principal ponto de inflexão no desenvolvimento de uma tradição especificamente brasileira de estudos sobre os chamados "grupos subalternos" na Antiguidade.

Essa foi para mim uma inspiração constante, ainda que, desde a iniciação científica, eu tivesse me voltado não para o testemunho direto dos subalternos (como os grafites), mas para uma leitura a contrapelo das fontes eruditas, em particular das cartas e sermões de Santo Agostinho. É uma prova da liberdade de escolha que o prof. Pedro Paulo sempre deixou aos seus orientandos que eu tivesse tomado esse caminho independente, o que é coerente com sua visão de educação (em todos os níveis) enquanto desenvolvimento da autoconsciência dos alunos. Mas a essa liberdade também correspondia seu constante questionamento, $\mathrm{o}$ que me levava a fundamentar melhor e em bases teóricas mais sólidas minhas afirmativas e opiniões. Lembro que em nossa primeira reunião de orientação ele me falava dos desafios de se fazer História Antiga no Brasil. Ainda que ressaltando as vantagens advindas do olhar periférico, brasileiro, o que nos permite propor temas e questões de um modo diverso dos centros hegemônicos, o prof. Pedro Paulo sempre nos estimulou a nós, seus orientandos, ao diálogo com a literatura científica universal, a estudarmos as fontes escritas em sua língua original, a conhecermos e confrontarmos diferentes tradições historiográficas. A ele devo, sobretudo, o ter-me feito ver ao longo dos anos de orientação na graduação e no mestrado a importância de confrontar diferentes tipos de fontes, de levar em conta a documentação arqueológica e de guardar o espírito crítico diante de todo discurso historiográfico. São essas características que fizeram do prof. Pedro Paulo Funari um dos principais formadores na área de História Antiga no Brasil e alguém que contribuiu de forma decisiva para elevar essa área do conhecimento histórico ao patamar que ela atinge hoje.

Seria longo mencionar em uma nota todo o impacto de sua obra, multifacetada, escrita em várias línguas e no diálogo entre diferentes disciplinas, da Arqueologia e a História, à Educação, ao Patrimônio, à Filosofia, às Letras e à História da Arte. Mas cabe ressaltar o seu esforço de criar as bases institucionais para o desenvolvimento da História 
Antiga em uma perspectiva interdisciplinar. Foi graças à sua iniciativa e à do prof. Hector Benoit que o Centro do Pensamento Antigo foi fundado naquele mesmo ano de 1995 que ingressei na universidade. O CPA congrega ainda hoje em encontros bienais pesquisadores de História Antiga, Arqueologia Clássica, Filosofia Antiga e Letras Clássicas em uma troca rara de experiências entre os praticantes dessas disciplinas. Toda a sua atuação em grupos e centros de pesquisa tem sido pautada por esse mesmo empenho de lançar as bases do desenvolvimento futuro da pesquisa pelas gerações que o sucederão. A doação recente de todo seu acervo bibliográfico e documental ao Departamento de História da UNIFESP é mais um exemplo de sua grandeza, de sua generosidade e de sua convicção de que o conhecimento não deve ser propriedade de privilegiados, mas instrumento de transformação coletiva. É para mim uma honra participar dessa justa homenagem e um prazer poder expressar aqui o meu reconhecimento a um mestre e amigo a quem devo muito do que sou como pesquisador e como professor. 